\section{Migration and the Problem of Old Age People in Nepal ${ }^{1}$}

\section{Tika Ram Gautam*}

\begin{abstract}
Current trends of migration in Nepal imply that the extensive out-migration of young people from rural areas, to foreign and internal urban centres, coincides with a rise in the problem of older couples in rural areas. This article examines the impact of migration on living condition and internal feelings of old age couples by drawing on the results of sociological and demographic field studies in Kandebash Village Development Committee (VDC) comprising multiethnic communities of western Nepal. The methodology for identifying older people is, social survey followed by direct interview with semi-structured questionnaire, examining variations by socio-economic strata and family structures. Comparative analysis indicates considerable heterogeneity in past and present migration patterns, both within and between countries. Economically higher status families are commonly able to reinforce their position by making better use of emigration opportunities. These families are migrating permanently to urban centers within country. Migrants from economically middle and lower status families are continuing temporary migration to foreign countries. Temporary migration, both within and between countries, is
\end{abstract}

1 This article is another form of research done in 1999 for MA dissertation. I am very much indebted to, Mr. Man Bahadur Khattri, my intimate colleague, of department of Sociology/Anthropology, MMC, Baglung, who contributed a lot providing important inputs to bring the article in this form. I would like to thank my fellow $\mathrm{Mr}$. Jiblal Gautam who help me completing survey.

* Lecturer and Head, Department of Sociology/Anthropology, MMC, Baglung. making old age couples alone in rural villages. The migrants' financial and material contributions are a nominal support. The old age lonely couples are facing many problems such as feeling loneliness, helplessness, frustration, increased household and social burdening.

Key words: Migration, emigration, immigration, old age couple, rural migration, Nepal.

\section{Background}

In the last two decades Nepal has experienced a dramatic growth in internal and international migration, especially from rural areas to urban centers and foreign countries such as America, Germany, Britian, Canada, Japan, Quatar, Arab, United Arab Emirates (UAE) and other countries including India. Some emigrants, who are able to earn sufficient cash money, are leaving their place of origin (home) and are moving to new places purchasing land and houses after the temporary emigration. Other emigrants are temporarily migrating to urban centers in the name of consuming modern facilities including their children's better education. Temporary migration is making old age couples alone in the rural villages. This article examines the problems faced by the old age couples, living lonely at home, after the temporary migration of their descendants. I argue that migration has been the leading phenomenon to many problems of old age couples in the rural villages of Nepal. Migration has created serious problems to old age couples burdening their roles in society and household level from sociological point of view. They have to compulsorily participate in all functions in society e.g. birth, marriage, festivals etc. occasions and death ritual including their personal, social and developmental activities in any way they could. 
Nepal has experienced considerable changes in population composition through spontaneous migration. Migration in the past was primarily directed eastwards along the hill corridor. Since the 1950s with malaria control in the lowlands, migration has been directed mainly towards the south (Gurung, 2001:11). It shows that migration took place from mountain and hill to eastward and inner terai at first and then to terai, in the south, region.

The largest and most dramatic population movements in recent years have occurred within the developing world. These often sudden and large-scale influxes endanger social and economic stability, particularly in countries already suffering from economic underdevelopment, political instability and ethnic tension (Schneller, 2001:2-3). Nepalese villages are still suffering from those problems although there is flow of remittances today.

Ethnic diversity is one of the main features of Nepal. It is because people from north, south, east and west including foreign countries immigrated here in the past. Only a few people have temporarily emigrated from Nepal. Most of them, who emigrated, were joined to Indian and British army and a few moved to Lahore as labour force. But these days, almost young and adult males from rural areas are emigrating to foreign countries. This emigration has created temporary internal migration. This migration phenomenon is creating serious problems to the old age couples from sociological point of view.

As mentioned above Nepal had been a country of destination for immigrants from both north and south. We do not have any Instances of emigration from Nepal before Sugauli
Treaty. However, after the Treaty of Sugauli (1816 AD), Nepalese people started to migrate to India to be recruited in the British Indian Army. The raising of the first Army Battalian (Sirmour Battalian) from among the Nepalese prisoners of war was the major turning point in the emigration of Nepalese people (Kanskar, 1984, quoted from Gautam, 2005). Of course, there were Nepalese from Kathmandu who used to go to Tibet for business but their numbers were limited. It was a very small scale and played insignificant role in Nepalese emigration phenomenon. Besides, the recruitment in British-Indian Army, new agricultural programmes, carried out by then British India in the provinces such as Assam, Darjelling, Burma attracted many peasants of Nepalese Hills to work and settle there. Later, many people also started to go to India. It still continues. Nepalese go to India to work as Watchmen (guards), hotel boys etc. and the recent trend is also going to Asian, European, American and United Arab Emirates (UAE) for skilled and unskilled jobs (Singh, 1998, quoted from Gautam, 2005). The history of emigration in Kandebash Village Development Committee (VDC) begins with a British Indian army in 1914 AD (Gautam, 1999).

Approximately 125 million people live outside their country of birth. The United Nations estimates that in the late 1990s, 2.6 million people migrated annually from less-developed to developed countries, seeking employment, reuniting with family, or fleeing conflict and persecution as refugees and internally displaced persons. (http://www.ssrc.org/ program...). It is true that Maoist conflict was and is one of the major reasons of emigration from past to present. Young males from rural Nepal are displaced due to conflict. But this number is very limited in this case (only 7 persons). Thus, 
Maoist Conflict has also become a major complementary reason for migration.

Movement of population across the international boarders of Nepal has two components. The first is emigration, or the Nepal born population reported as absentees abroad, and second, immigration or the foreign-born population reported within Nepal (Gurung, 2001:13). Migration movements of the high mountain regions of the Nepal Himalaya are as long as those out of all other high mountain regions in the world, and have described by migration research since 1970s. But the real dimensions of the actual emigration wave out of the hills and mountains of Nepal became evident for the first time with the results of the 1981 population census (Hoffman, 2001:116). There are no empirical records on emigration till 1951. The 1952/54 census of Nepal was the first to report the volume of emigration from Nepal.

\section{Present Scenario}

Migration has multiple effects in the point of origin i.e. in Nepal. While walking along the rural villages of western Nepal, we could see old couples alone at their homes. Some one, who visits, assumes the old couples have no offspring. But the reality is different. If the old couples were asked, the couples would say that they were not alone before and are not still because they have children. Their daughters have married and gone to their homes. Sons are either in foreign countries or in urban centers. Grandchildren are together with son or daughter in law. The old age couples are now looking after the empty homes waiting for children in the hope of meeting each other and staying together sooner or later in the future.
Young and adult migrants are largely moving for economic reasons. They afford various modern facilities (television, mobile cell, car, motorbike, computer, internet, readymade clothes etc.) and take food and breakfast prepared in standard hotels and restaurants in foreign countries. While they return back to their villages, they feel various difficulties including consumption of modern utilities. Migrants' level and pattern of consumption are changing continuously. Their expectation towards the future of their children is found highly increased. They, therefore, focus their spouse and children rather than old age parents. On the other hand, migrant's wife living at home convinces her husband move to urban centers leaving old couples at home. Migrant is unable to reject his spouse and suggests her to stay in urban centers educating their children. Thus old age couples are being alone in villages. This circumstance is leading the old age couples face physical and mental problems.

\section{Methodology}

Galkot, midwestern part of Baglung district, is known as place of lahure (emigrant return from Lahore-a foreign country) since very long (approx. 1914 AD) and the flow of people from the area is still very high. Particularly Kandebash VDC is selected as the base for this study, because it seems to be of typical localities as origin of migrants of different caste, class and ethnic groups.

Household survey was made before sampling. For this, total households (HHs) were listed at first. It was 441 in total. Total population is 2496 with 1195 females (Gautam, 1999). Among the total 441 households migrants' households were listed as 203 HHs. Population of migrant's families is found 1263 including 679 females. Total number of migrants from 
$203 \mathrm{HHs}$ is 283 . Out of these 283 migrants, 226 are emigrants and remaining 57 are internal migrants.

Before taking sample, old couples in the villages were listed. Among all, 22 couples were found alone. Similarly, 63 HHs are lacking adult males. These 22 old couples are census of this study. This population includes Brahmin 15, Chhettri 4, Dalit (B.K.) 2 and Magar 1. Information was generated from these 22 old couples using semi-structured questionnaire, personal interviews and focus group discussion. Questionnaire and interviews were used for each old couple while focus group discussion was done with schoolteacher, other families with adult descendants children and migrants. A fellow completed the survey questionnaire given. Old couples were interviewed for sensitive personal information and their feelings.

\section{Socio-economic Features of Migrants}

\subsection{Caste/Ethnic composition of Migrants}

Major caste/ethnic groups in the study area are Brahmin, Chhetri, Dalit (Kami and Damai), Thakali, Magar and Gurung. The composition of the population is given in table 1.

Table 1: Caste/ethnic composition of migrants' HHs and population

\begin{tabular}{|l|l|l|l|l|}
\hline S.N. & $\begin{array}{c}\text { Caste/Ethnic } \\
\text { Group }\end{array}$ & HHs & Population & Migrants \\
\hline 1. & Brahmin & 118 & 786 & 167 \\
\hline 2. & Chhetri & 53 & 200 & 70 \\
\hline 3. & Kami & 23 & 208 & 32 \\
\hline 4. & Magar & 8 & 65 & 13 \\
\hline 5. & Thakali & 1 & 4 & 1 \\
\hline & Total & 203 & 1263 & 283 \\
\hline
\end{tabular}

Source: Field Survey, 2008

Migrants from the study area are proportionate to various caste/ethnic groups. Before a decade migrants from high caste Brahmin was higher i.e. 57.9 percent (see Gautam, 1999:50) than other caste/ethnic group in comparison to HHs. But these days, migrants from Kami, Magar and Chheti are higher than those of Brahmin. Table No. 1 shows the clear figure of HHs, population and migrants' composition.

\subsection{Place of Destination}

Since very beginning people in this area are going to neighboring country, India. But since last 10-15 years, migrants are changing their destination. It is because they are looking for better job salary compared to Indian currency. The study area, Galkot, is often known as place of lahure foreign migrant, especially to Japan. But now they are migrating to various countries including certain urban centers in Nepal. Places of destination are given in table 2.

Table 2: Place of migrants' destination

\begin{tabular}{|c|c|c|c|}
\hline S.N. & $\begin{array}{l}\text { Place of Destination ( Nepal } \\
\text { and Foreign Country) }\end{array}$ & $\begin{array}{l}\text { No. of } \\
\text { Individual }\end{array}$ & Percentage \\
\hline 1. & $\begin{array}{l}\text { Internal Cities in Nepal (For } \\
\text { Job and Study) }\end{array}$ & 57 & 20.14 \\
\hline 2. & $\begin{array}{l}\text { India-Delhi and other cities } \\
\text { (Neighbouring country) }\end{array}$ & 110 & 38.96 \\
\hline 3. & $\begin{array}{ll}\text { Kuwait/Qatar/ Saudi } & \text { Arab, } \\
\text { Bahrain and UAE } & \\
\text { (Less developed } & \text { Asian } \\
\text { countries) } & \end{array}$ & 54 & 19.05 \\
\hline 4. & $\begin{array}{l}\text { Japan/Singapore/Malaysia/Kore } \\
\text { a/China } \\
\text { (More developed Asian } \\
\text { countries) }\end{array}$ & 39 & 13.75 \\
\hline
\end{tabular}




\begin{tabular}{|c|l|c|c|}
\hline 5. & $\begin{array}{l}\text { Germany/Belgium/Switzerland/ } \\
\text { Denmark/UK/Spain } \\
\text { (European countries) }\end{array}$ & 16 & 5.65 \\
\hline 6. & $\begin{array}{l}\text { America/Canada (North } \\
\text { American countries) }\end{array}$ & 5 & 1.75 \\
\hline 7. & Australia & 2 & 0.70 \\
\hline & Total & 283 & 100.00 \\
\hline
\end{tabular}

Source: Field Survey, 2008

Largest number (38.96 percent) of people is still in Indian cities. It is because of two reasons. Firstly, Indian cities were previously easy accessible to all Nepalese as Nepal-India has open boarder and cheap to and fro (transportation fair) expenses since 1950s. Secondly, most of the people go to India to develop skill to have better jobs in India or to leave for third country. The latter one is still dominant reason. Second largest number of migrants' is of Saudi/Qatar/UAE (19.5 percent) followed by Japan/Singapore and other developed Asian countries (13.75 percent). Similarly the number of emigrants in European countries is also quite larger (5.65 percent) in comparison to access from cost and visa processing in European countries. Number of migrants to Saudi/Qatar/UAE is increasing because it has now been easily accessible from cost and visa point of view. These countries demand physically strong young males for hard labour. So economically weak people can also apply because visa is easily accepted.

\subsection{Level of Earning}

Migrants are changing their place of destination for better job and salary. They are intending to go in more developed countries with higher currency value. Most of the migrants are going to third countries from their previous destination,
India. Some of the new migrants are directly migrating to foreign countries from Nepal through direct contact and investment. The old couples were asked about their level of earning. The responses from them are given in table 3 .

Table 3: Attitude of old couple towards level of earning of migrants'

\begin{tabular}{|l|l|l|l|}
\hline S.N. & \multicolumn{1}{|c|}{ Migrant's Level of Earning } & $\begin{array}{c}\text { No. of } \\
\text { Individual } \\
\text { Migrants }\end{array}$ & Percentage \\
\hline 1. & $\begin{array}{l}\text { Nothing (same as it was } \\
\text { before) }\end{array}$ & 6 & 27.27 \\
\hline 2. & $\begin{array}{l}\text { Just livelihood support (no } \\
\text { family debt and income is } \\
\text { spent on basic needs) }\end{array}$ & 36.36 \\
\hline 3. & $\begin{array}{l}\text { Satisfactory (small amount is } \\
\text { saved but is being spent on } \\
\text { modern utilities) }\end{array}$ & 6 & 27.27 \\
\hline 4. & $\begin{array}{l}\text { Enough (some amount is save } \\
\text { and something, land or home, } \\
\text { is bought in new place) }\end{array}$ & 2 & 9.1 \\
\hline & Total & 22 & 100.00 \\
\hline
\end{tabular}

Source: Field Survey, 2008

Though migrants to foreign countries are in large scale there is no significant change in their lives. Twenty seven percent migrants' families remained the same as it was before. Most of the migrants (36 percent) have maintained basic thing to support their lives. Among all, 27 percent are spending their income in modern facilities including educating their children migrating to urban centers. Only 9 percent migrants' are being able to buy land and home and moved permanently from their origin. It seems that middle class (from income 
point of view) migrants are leaving the old age couple at their homes.

\section{Major Problems Faced by Old Couples}

As we have mentioned above, number of old couples living along in the villages is increasing. It is due to temporary migration of young and adult males and females including their children. Old couples, living in the villages, are facing many problems though they have some cash. Some major problems faced by them are mentioned here in table 4 .

Table 4: Major problems faced by old couples

\begin{tabular}{|l|l|l|l|l|}
\hline S.N. & $\begin{array}{l}\text { Major } \\
\text { Problems }\end{array}$ & Major Reasons no.* & Percentage \\
\hline 1. & Anxiety & $\begin{array}{l}\text { Remembering no } \\
\text { offspring, } \\
\text { frequent meeting, } \\
\text { hearing incidents }\end{array}$ & 14 & 63.63 \\
\hline 2. & Extra burden & $\begin{array}{l}\text { Everything has to } \\
\text { be done alone } \\
\text { (E.g. Household, } \\
\text { social, cultural, } \\
\text { economic) }\end{array}$ & 90.90 \\
\hline 3. & Helplessness & $\begin{array}{l}\text { No one is with us } \\
\text { while we are } \\
\text { physically weak or } \\
\text { ill, or to work }\end{array}$ & 81.81 \\
\hline 4. & $\begin{array}{l}\text { Loneliness } \\
\text { feeling }\end{array}$ & $\begin{array}{l}\text { No one is at home, } \\
\text { no one to speak }\end{array}$ & 70.70 \\
\hline
\end{tabular}

Source: Field Survey, 2008

\footnotetext{
* Number and percentage is calculated from 22 respondents because each question is asked to each respondent.
}

It is said that migration has well supported to the rural economy of Nepal. It is partly true because it has just provided cash for the family members. It cannot provide humanitarian support to the family members especially to old couples. So they are not tension free even if they have lots of cash in hand. The old couples, 90 percent, are loaded with extra physical, household, social and cultural burdens. Similarly 81 percent feel helpless although they have few children. Most of the couples i.e. 70 percent feel loneliness and 63 percent are anxious after their children's migration. Each problem is discussed here in detail.

\section{Anxiety}

Anxiety is the result of sadness, psychological tensions and other social and cultural burdens. The old couples in the village are not happy even though their offspring are doing better economically after migration. The old couples think each and every time about their offspring. They seem more anxious when they hear about events like accidents, killing, murder and fighting through various communication Medias. They often remember them and could not sleep over the night. The feeling of couple in the area is presented in table 5.

Table 5: Feeling of old couple

\begin{tabular}{|c|c|c|c|}
\hline S.N. & Types of Feeling/Problem & No. & Percentage \\
\hline 1. & Very sad & 4 & 18.18 \\
\hline 2. & Sad & 11 & 50.00 \\
\hline 3. & Still quite satisfactory & 5 & 22.72 \\
\hline 4. & Happy & 2 & 9.10 \\
\hline & Total & 22 & 100.00 \\
\hline
\end{tabular}

Source: Field Survey, 2008 
In the field study one question was asked to know their feelings as happy or sorrow. Ninety percent of the couples are feeling unhappy while living alone at home even though they have cash support. Hundred percent old couples expressed their views that they would feel happy if the whole family members were together. Most of the couple's eyes were wet with tear while talking about their son in foreign cities.

\section{Extra Burden}

The old couples staying at home are now compelled to participate in all activities from kitchen to public meeting and birth to death rituals. Major burdens over them are kitchen works, animal husbandry in shed, compulsory labour contribution in social and public activities, member of wedding party, a mourner at a funeral, helping everyday activities to neighbour, participation and performance of cultural activities. The leader of social and developmental activities often talk about rejecting old people in labour contribution because they are physically weak and cannot contribute as other young labour force. They explained that physical activities have been more difficult for them because thy have left to do before their offspring have migrated. The old age lonely couples are now overloaded with those burderns.

\section{Helplessness}

Old age couples feel physically tired and weak while working. But they have to do all activities since very morning to the evening each day. They could find no one to help even if they are sick. The couples have to persue neighbour to perform any activities. Other villagers do not frequently come to visit and talk to them. They could not find anyone to serve while they suddenly become ill. The old couples often say "chhora chhori payo, hurkayo, badhayo, aakhir kehi pani chhaina" (we raise children but no one is with us now). They feel helpless during such circumstances. So helplessness has become another major problem of old couples.

\section{Loneliness Feeling}

The couples are not physically alone because they are in couples. But psychologically they are alone at home. They feel the environment alone because they could see no young, adult and children around. They have no one to work and live together. There is no one to support them in various activities from morning to night. The old couples are suffering from such loneliness that Shrestha (2001) writes about shadow life of migrant's wife, "one can find scattered historical accounts of pain and loneliness suffered by the wives and children of countless fortune-seeking migrants." Sometimes they wonder whether they had children or not. They, thus, are suffering from loneliness feeling.

\section{What Do the Old Age Couples Want?}

The old couples are not satisfied. They are intended to leave their home village if they could have better options with more facilities. Most of the couples have no chance of choosing for living places. Their desire is given in table 6.

Table 6: Desires of old couples

\begin{tabular}{|c|l|l|l|}
\hline SN. & Desire to do & No. & Percentage \\
\hline 1. & $\begin{array}{l}\text { Intend to leave their } \\
\text { home }\end{array}$ & 13 & 59.09 \\
\hline 2. & Not intended to leave & 4 & 18.18 \\
\hline 3. & $\begin{array}{l}\text { Strong desire to move } \\
\text { to new places }\end{array}$ & 5 & 22.73 \\
\hline & Total & 22 & 100.00 \\
\hline
\end{tabular}

Source: Field Survey, 2008 
The old couples have strong desire to leave the village and move to urban centers where there are more facilities. About 59 percent couples have such desire. It is because of extra burden and helplessness. But they think that it will be very difficult to leave their settlements. Only few couples, 18 percent are not desirous to leave their birthplace. It means that people like to leave their place of birth if they have enough money for new settlement.

\section{Conclusion}

Migration phenomenon to Nepalese villages is not recent one. It has very long history and the pattern of migration is increasing these days. Migration in western Nepal follows the patterns of international migration. Increasing migration has not only positive implications but also many negative impacts. One of those problems is of old couple. The number of old couple living alone in the villages is increasing. These old couples are facing many new problems they did not have in the past.

Major problems faced by the old couples are anxiety, helplessness, loneliness feeling, and increased social and cultural burdens including household ones. Their lives have become isolated. They, therefore, intended to go to better places having modern facilities. But they think it is better to live together with all family members rather than to move towards new places.

\section{Reference}

Gautam, Tika Ram. (2005). Causes and Impact of Migration: A Sociological Study of Emigration from Kandebash, Baglung, Nepal. Baglung. Dhaulagiri Journal of Sociology and Anthropology.
Gautam, Tika Ram. (1999). Labour Migration to India: A Case of Emigration from Kandebash VDC, Baglung. A Dissertation Submitted to Central Department of Sociology/Anthropology. Kirtipur. T.U.

Schneller, Martin. (2001). The Impact of Migration on the Stability of the international System. Aspects of Migration and Mobility in Nepal, Susanne Von der Heide and Thomas Hoffman (ed). Kathmandu. Ratna Pustak Bhandar.

Gurung, Harka. (2001). Highlanders on the Move: The Migration Trend in Nepal. Aspects of Migration and Mobility in Nepal, Susanne Von der Heide and Thomas Hoffman (ed). Kathmandu. Ratna Pustak Bhandar.

Hoffman, Thomas. (2001). Out-Migration Patterns of SoluKhumbu District. Aspects of Migration and Mobility in Nepal, Susanne Von der Heide and Thomas Hoffman (ed). Kathmandu. Ratna Pustak Bhandar.

Shrestha, Nanda. (2001). The Shadow Life of Migrant's Wife. Aspects of Migration and Mobility in Nepal, Susanne Von der Heide and Thomas Hoffman (ed). Kathmandu. Ratna Pustak Bhandar.

http://www.ssrc.org/program_areas/migration/?gclid=CPvRmC1y5ECFQw2egodyE-e2w 
